\title{
Trends and Challenges in Food System Management in Emerging Economies: \\ A Comparative Analysis between Romania and Poland
}

Robert BUMBAC ${ }^{1}$

Abstract
The food system became one of the most important concern of the $21^{\text {st }}$ century
both in terms of food security and sustainability. The complex dynamics and
unpredictability in food industry have a significant impact especially on emerging
economies in which income growth and demographic changes are more pronounced
and the focused in food system management is more on economic aspects rather than
on sustainability. Especially in developing countries the price of food doesn't reflect
the environmental and social costs it has in a global perspective, allowing a
displacement of environmental costs of food production through trade from high-
income to low-income countries. A secondary data analysis was performed to identify
the main changes and how emerging countries adapted their food system management.
Romania and Poland were the subject of the investigation, considering their important
evolution and the central role of food industry in their case.

Keywords: food system management, emerging economies, food sustainability, challenges and trends

JEL classification: M11, M14, L66

DOI: $10.24818 /$ RMCI.2019.4.491

\section{Introduction}

One important challenge nowadays is to create a more sustainable production and consumption food system and this can be made only by empowering all the stakeholders involved in food production, processing, distribution, storage and consumption. The focus should be more on how to increase the productivity of natural resources used in creating food rather than productivity in terms of revenues and financial costs (Holzeis et al., 2019). Thus, the Food System Management (FSM) should be aligned with the new scientific knowledge in this field, understanding the global risks and finding the best solutions to support interregional and international trade.

The objective of the paper is to identify main trends and challenges in FSM and particularly their impact in emerging economies. In this regard Romania and Poland were chosen, being two representative countries in Eastern Europe with a significant increase of their food system. The comparative analysis between the two

${ }^{1}$ Robert Bumbac, The Bucharest University of Economic Studies, E-mail: robert.bumbac@ com.ase.ro 
countries focused especially on changes that have occurred and how these adapted their FSM to global challenges and trends that shaped continuously the food industry.

There were plenty of studies published on changes and risks with a major impact on the food industry but none of them focused on their impact on emerging economies as Romania and Poland. Thus, the study can be a useful approach in better understanding the impact of global changes on the sustainability of FSM and consumption patterns in emerging economies.

The study follows the perspective of Bene et al. (2019) according to which "there is an urgent need to better understand the ways in which food systems are currently evolving"(Bene et al., 2019).

\section{Food System Management}

Food systems are explained as socio-ecological systems with powerful links between food, agriculture and environmental change (Bers et al., 2019) that has as main role to assure food security in a sustainable way. Thus, an important role of food systems is to control the level of greenhouse gas emission, degradation and misuse of resources and loss of biodiversity (Holzeis et al., 2019). This goals are harder to be reached considering the increasing global demand for food and the fact that food systems are globally interconnected and interdependent with the environment in terms of resource availability, degradation, climate change and also with other social factors that changed labour availability and consumption patterns (Bers et al., 2019).

Food System Management is explained as the governance of all activities, actors, processes, infrastructure, flows and outcomes in the production, processing, distribution and consumption of food considering their socio-economic and environmental impact (Bene et al., 2019; Bers et al., 2019). Seeing all the changes that shaped the food system in the last 20 years, especially by "abrupt transformations" (Reardon et al., 2019), innovation played a significant role in the improvement of FSM especially in terms of productivity and manufacturing technologies for processing, logistics, packaging and commerce activities (Reardon et al., 2019). The European Commission proposed a graphical representation of the link between FSM and innovation, being two interconnected activities dependent on each other to face global threats, as presented in Figure 1.

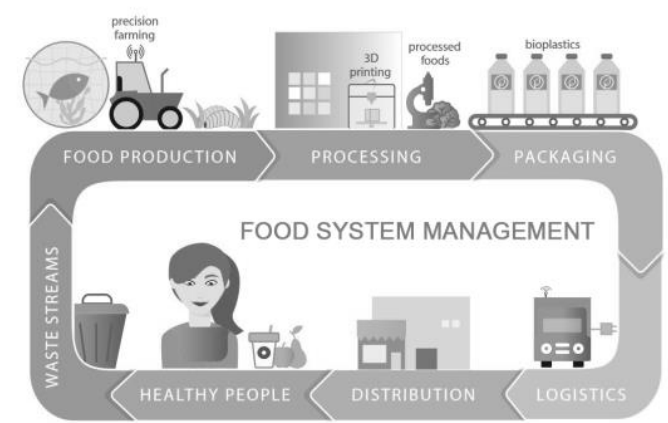

Figure 1. Innovation in Food System Management

Source: Adapted after European Commission (2018) 
Especially responsible innovation is important when it comes to environment aspects that companies in the food industry should consider. Companies as Nestle, Unilever and Tetrapack investigated different ways throughout the entire life cycle of their products in which to adapt and improve them to be more environmental friendly. Also food retailers and supermarket chains as Tesco and Leclerc evaluated the environmental footprint of the products they sell (Notarnicola et al., 2017). At the same time innovation role is to contribute to the increase of productivity and to ensure food security. Even if undernourishment is generally associated with low-income countries, the latest studies showed that even in high-income countries from Europe there are a considerable percentage of households that don't have enough resources to meet their calories requirements (Holzeis et al., 2019) and this remains a challenge in the innovation process of the industry.

\section{Trends in the Food System Management}

A good example of using new technologies in food industry is represented by the improvement in the control of goods' properties during their entire life cycle. Thus, food tracing and tracking were included in FSM, as part of food inspection and certification system in order to avoid food hazards and to maintain food safety at an optimal level (Chaoniruthisai, Punnakitikashem and Rajchamaha, 2018). Even if the cost of this technology remains still high it has an important contribution in avoiding fraud and winning consumers' trust through interactive communication (Chaoniruthisai, Punnakitikashem and Rajchamaha, 2018).

Sustainable Food System is another important trend, discussed in the literature that suppose managing the food system to be more productive and to achieve food security. At the same time the economic, social and environmental impact of FSM on the population has to be positive, especially through a nutrition improvement (FAO, 2018). Also this can be reached through an increase in the resilience of agriculture and food system to climate change and a development of high quality and safe food (Notarnicola et al., 2017).

Food security cannot be reached only by improvements in production but also through the adaption of consumption patterns and a better use of existent resources, particularly through waste reduction. In this regard circular bioeconomy is an important trend that suppose the optimum use of natural resources, reducing food lose and waste and also reusing raw materials and different products. This can be reached also through the adoption of better production practices that allow environmental friendly techniques (FAO, 2019).

\section{Research Methodology}

In order to accomplish the objectives of the current study a secondary data analysis was performed to identify the main changes in the food system of Romania and Poland, both emerging countries in Eastern Europe and members of 
the European Union. Statistic data provided by the Food and Agriculture Organization of the United Nations (FAO) was used in calculating relevant indicators for the food system management and creating visual relevant figure needed for the comparative analysis. The most recent data available, published by FAO in 2019 reflects records until 2017, thus the investigation took into consideration a 20 years' time frame between 1997 and 2017. Among the most important data included in the study was: food production, imports and exports, net trade, average dietary energy supply, agriculture land area, employment and value added per worker in agriculture, urban and rural population evolution, adult obesity. Besides Romania, Poland was selected for this case study because it has a good integrated food system with high production and trade capacities, being and important player in Eastern Europe that merit to be studied and followed in best practices.

\section{How emerging countries manage challenges affecting the Food System Management: a comparison between Romania and Poland}

A common challenge encounter by emerging economies is income growth of the population which led to an increase in demand for meat and indirect increase in the production of cereals. Both Romania and Poland recorded an important increase in GDP per capita in the last 20 years with an annual average rate of growth of $+4.14 \%$ for Romania and $+3.14 \%$ for Poland. The evolution is mainly a positive one considering the improved live conditions once with the accession to the European Union and the important funds invested in agriculture and food industry. At the same time, income growth represented a pressure on the extensive use of the natural resources and at the same time powered by an uneducated diet among the majority of the population, increasing the consumption of processed food with low nutrients and thus a negative impact on the health status of the population. This is proved also by the increase of adult obesity with $+7.5 \%$ for Romania and $+7 \%$ for Poland in the last 20 years.

Table 1. Income growth and obesity of adult population in Romania and Poland

\begin{tabular}{|l|c|c|c|c|c|}
\hline \multicolumn{1}{|c|}{ Country / indicator / year } & $\mathbf{1 9 9 7}$ & $\mathbf{2 0 0 7}$ & $\mathbf{2 0 1 7}$ & $\begin{array}{c}\text { Relative } \\
\text { change in the } \\
\text { last 20 years }\end{array}$ & $\begin{array}{c}\text { Annual } \\
\text { average rates } \\
\text { of evolution }\end{array}$ \\
\hline Romania & & & & & \\
GDP per capita (USD, PPP) & 10419 & 17065 & 23442 & $+124 \%$ & $+4.14 \%$ \\
Adult obesity (\% of adult pop.) & 17.0 & 19.6 & 24.5 & $+44 \%$ & $+1.84 \%$ \\
\hline Poland & & & & & $+86 \%$ \\
GDP per capita (USD, PPP) & 14733 & 19563 & 27346 & $+38 \%$ & $+1.61 \%$ \\
Adult obesity (\% of adult pop.) & 18.6 & 21.1 & 25.6 & $+3.14 \%$ \\
\hline
\end{tabular}

Source: Own calculation based on FAO data (2019b) 
Food poverty is another issue especially for emerging countries, explained as a form of food insecurity which involves acquiring a limited or uncertain quantity and quality of food, which has an important influence on health in terms of malnutrition and obesity (Thompson, Smith and Cummins, 2018). In this category there are included poorer households that don't afford enough quality food, thus often they buy low in nutrients and energy dense food.

An important contribution to food poverty had also demographic changes which registered a higher dynamics for emerging countries as Romania and Poland. Especially their impact on FSM was that unprecedented urban growth (FAO, 2019) lead to a decrease in food supply, an increase of the overweight and obese population and an important change in consumption habits in terms of an increase accessibility and preference for processed food with low nutrients. In Romania even if the urbanization trend is relatively reduced $-1 \%$ compared to the general world percentage of $-10 \%$, in Romania it was recorded an increasing migration towards foreign countries and thus the depopulation of both rural and urban areas recorded significant values (Rey, 2015). In Poland case there was managed a slight increase of the rural population $+1 \%$ and a considerably lower decrease of its total population even if the share of rural population is above the world average, there are better conditions to cover the labour force needed in agriculture and food industry. As a general trend in European countries the elderly population is increasing and this leads to even a greater pressure on FSM in terms of human resources that can be involved in the agriculture and food industry.

Both Romania and Poland have abundant natural resources and clear food safety and quality standards, this field being well regulated by European Union legislation.

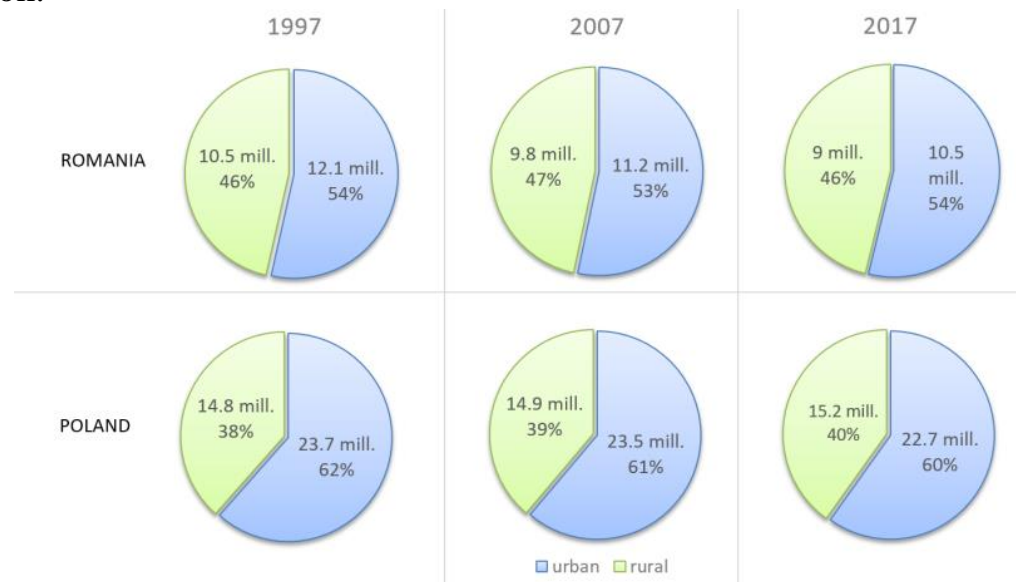

Figure 2. Urban vs. rural population evolution in Romania and Poland Source: Own representation based on FAO (2019b)

A particularity for emerging countries is sometimes the lack of ability to put into practice, to adopt and to comply with all the standards created at European level. Even if for Romania and Poland there are plenty of natural resources, increasing the efficiency of the land use become more important also in their case 
once with the use of agricultural land for other purposes as urbanisation and bioenergy (Notarnicola et al., 2017). At global level $40 \%$ is land used for agriculture and $70 \%$ water withdrawals used especially for irrigations. The necessary of freshwater is increasing even more in emerging economies where the urban sector develops and higher quantities of fresh water are requested considering also the impact of polluted water (Holzeis et al., 2019).

Ray (2015) identified also the negative impact of deforestation and degradation of grasslands and biodiversity especially in the case of Romanian mountain farmers. In Poland case the percentage of the total land area recorded a higher decrease of $-21.72 \%$ compared to Romania that reduce the agricultural land used only by $-9.92 \%$ in the last 20 years. This situation reflect that agriculture remains one of the major activities among Romanians. At the same time this percentage is almost double than the constant percentage recorded worldwide of $37 \%$ (FAO, 2019b) compensating certain closed agriculture areas with new opened ones in other regions.

Table 2: Agriculture land area in Romania and Poland (\% of total land area)

\begin{tabular}{|c|c|c|c|c|}
\hline Country / year & $\mathbf{1 9 9 7}$ & $\mathbf{2 0 0 7}$ & $\mathbf{2 0 1 7}$ & Relative change in the last 20 years \\
\hline Romania & 64.5 & 59.3 & 58.1 & $-9.92 \%$ \\
\hline Poland & 60.3 & 50.5 & 47.2 & $-21.72 \%$ \\
\hline
\end{tabular}

Source: Own calculation based on FAO data (2019b)

The decrease in the agriculture land area used can be explained also by a decline of the employment in this domain. More than demographic changes that affect the employment in agriculture and food industry also the absence of vocational schools and the lack of specialized education had a major contribution to this negative trend in emerging countries as Romania. Although the accession to EU for Poland it represented mainly an important benefit for their economic performances there was also a negative impact on small farmers required to apply more restrictive regulation and policies in agriculture (Mroczkowska, 2019). This could also explain the reduction in the number of workers in agriculture which seems to have a constant decrease between $44 \%-51 \%$ in the last 20 years for both Romania and Poland.

Table 3. Employment and value added per worker in agriculture in Romania and Poland (\%)

\begin{tabular}{|c|c|c|c|c|c|}
\hline Country / indicator / year & 1997 & 2007 & 2017 & $\begin{array}{c}\text { Relative } \\
\text { change in the } \\
\text { last } 20 \text { years }\end{array}$ & $\begin{array}{c}\text { Relative } \\
\text { change in the } \\
\text { last } 10 \text { years }\end{array}$ \\
\hline Romania & \multirow{3}{*}{$\begin{array}{l}40.9 \\
2435\end{array}$} & \multirow{3}{*}{$\begin{array}{l}29.5 \\
3032\end{array}$} & \multirow{3}{*}{$\begin{array}{r}22.8 \\
5769\end{array}$} & \multirow{3}{*}{$\begin{array}{l}-44.25 \% \\
+136.92 \%\end{array}$} & \multirow{3}{*}{$\begin{array}{l}-22.71 \% \\
+90.27 \%\end{array}$} \\
\hline Employment in agriculture (\%) & & & & & \\
\hline $\begin{array}{l}\text { Agriculture value added per } \\
\text { worker (constant USD) }\end{array}$ & & & & & \\
\hline
\end{tabular}




\begin{tabular}{|l|c|c|c|c|c|}
\hline \multicolumn{1}{|c|}{ Country / indicator / year } & $\mathbf{1 9 9 7}$ & $\mathbf{2 0 0 7}$ & $\mathbf{2 0 1 7}$ & $\begin{array}{c}\text { Relative } \\
\text { change in the } \\
\text { last 20 years }\end{array}$ & $\begin{array}{c}\text { Relative } \\
\text { change in the } \\
\text { last 10 years }\end{array}$ \\
\hline $\begin{array}{l}\text { Poland } \\
\begin{array}{l}\text { Employment in agriculture (\%) } \\
\text { Agriculture value added per } \\
\text { worker (constant USD) }\end{array}\end{array}$ & 21.2 & 14.7 & 10.2 & $-51.89 \%$ & $-30.61 \%$ \\
\end{tabular}

Source: Own calculation based on FAO data (2019b)

The decrease in the employment rate was compensated by technologies and innovation that changed agriculture and food industry and also thanks to the higher funds and facilities offer for this domain. The decrease of employment in agriculture is a general trend worldwide, both Romanian and Poland recording a reduced number of workers in agriculture, mainly because of the more attractive industries and activities that appeared and also because of the increased technology that is currently used, which substantially improves efficiency and effectiveness of this activity. An important difference in employment rate in agriculture it can be seen particularly in the evolution of the last 10 years in Romania, recording the highest increase in value added per worker (+90.27\%) compared to Poland case where the increase was only of $+22.26 \%$. For Romania these important progress is largely due to the accession to the European Union which supposed important funds and a better transfer of know-how and technology. At the same time there could be identified some negative effects with a much lower impact. Rey (2015) explains the decrease in the number of young people and small producers involved in the agriculture and food industry in Romania because of the smaller amount of money they receive on their products as more middlemen and processors arise in the supply chain and influenced in a negative way their earnings.

Lack of sustainability perspective it can be another problem of emerging economies. If in developed countries the approach is to supply food in a sustainable and stable manner to help the local economy, in developing countries the focus is mainly on identifying lacking capacities or food crises and supporting them through policies and funds in dealing with challenges and improving their FSM to reach a better food security level (Himanen, Rikkonen and Kahiluoto, 2016). Both in Romania and Poland we can identify isolated entrepreneurship activities towards green agriculture and slow food industry, with an increase in the last years but still at the beginning of their development. Sustainability can be reach on one hand through the increase in rational productivity and especially in the regions with growing entrepreneurship using the land for organic agriculture (Bórawski et al., 2019). One the other hand one of the most influent way to increase sustainability of the FSM is through dietary transformation as for example in reducing meat consumption (Notarnicola et al., 2017). 


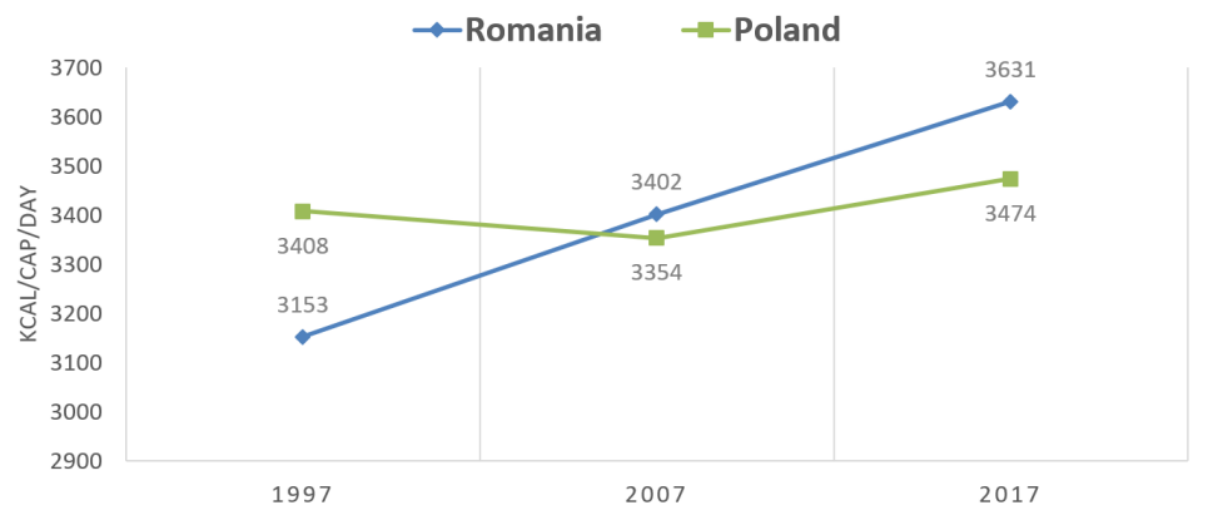

Figure 3. Average dietary energy supply in Romania and Poland (kcal/cap/day) Source: Own representation based on FAO (2019b)

Both Romania and Poland are among the first 20 countries worldwide with a high average of energy supply, Romania is ranked $6^{\text {th }}$ with $3631 \mathrm{kcal} / \mathrm{cap} / \mathrm{day}$ and Poland on the $15^{\text {th }}$ place with $3474 \mathrm{kcal} / \mathrm{cap} /$ day $(\mathrm{FAO}, 2019 \mathrm{~b}$ ). The difference between the two analyzed countris is that Romania recorded an important increase in the last twenty years with aprox. $+400 \mathrm{kcal} /$ capita/day while Poland recorded only a smaller rise with aprox. $+50 \mathrm{kcal} /$ capita/day (FAO, 2019b).

Considering these aspects, food production has a significant role in assuring the adequate quantity and quality of food both in terms of nutritional composition and socio-cultural preferences (Notarnicola et al., 2017). At the same time there is a direct relation between food production and preservation of natural resources (land, water, energy) and biodiversity (Holzeis et al., 2019). As it can be seen Romania reached in the last years a similar food production value per capita compare to Poland. The price of foodstock increased and these can also explain the value increase of food production.

Table 4. Food production in Romania and Poland

\begin{tabular}{|c|c|c|c|c|c|}
\hline Country / indicator & 1997 & 2007 & 2017 & $\begin{array}{c}\text { Relative change } \\
\text { in the last } 20 \\
\text { years }\end{array}$ & $\begin{array}{c}\text { Annual average } \\
\text { rates of } \\
\text { evolution }\end{array}$ \\
\hline $\begin{array}{l}\text { Romania } \\
\text { Food production value } \\
\text { (2004-06, mill. USD) } \\
\text { Food production value per capita } \\
\text { (2004-06, USD) }\end{array}$ & $\begin{array}{r}10570 \\
468\end{array}$ & $\begin{array}{r}8056 \\
384\end{array}$ & $\begin{array}{r}11486 \\
589\end{array}$ & $\begin{array}{l}+8.67 \% \\
+25.94 \%\end{array}$ & $\begin{array}{l}+0.42 \% \\
+1.16 \%\end{array}$ \\
\hline $\begin{array}{l}\text { Poland } \\
\text { Food production value } \\
\text { (2004-06, mill. USD) } \\
\text { Food production value per capita } \\
\text { (2004-06, USD) }\end{array}$ & $\begin{array}{r}20021 \\
520\end{array}$ & $\begin{array}{r}20215 \\
526\end{array}$ & $\begin{array}{r}22479 \\
593\end{array}$ & $\begin{array}{l}+12.28 \% \\
+14.05 \%\end{array}$ & $\begin{array}{l}+0.58 \% \\
+0.66 \%\end{array}$ \\
\hline
\end{tabular}

Source: Own calculation based on FAO data (2019b) 
In providing the necessary food quantities on the market, trade has an increasingly important role in emerging economies. In terms of imports and exports of food products there is a significant difference between the two analysed countries. Poland is a net food exporter in Europe having advanced technologies in food processing industry and also good food supply chains among EU countries. In the last 10 years, mainly after EU accession the import quantities increased a lot on the Romania market, in many years exceeding the level of exports. Under the pressure of high imports on the Romania food market and a higher competition in terms of price, local companies should invest in food safety and quality management in order to compete with imported products. There was some initiatives to encourage more the consumption of local products but the results were limited considering the importance of price among the majority of the population and the restricted possibilities of local producers to assure an sustain a constant flow of products compared to big players of the European market.
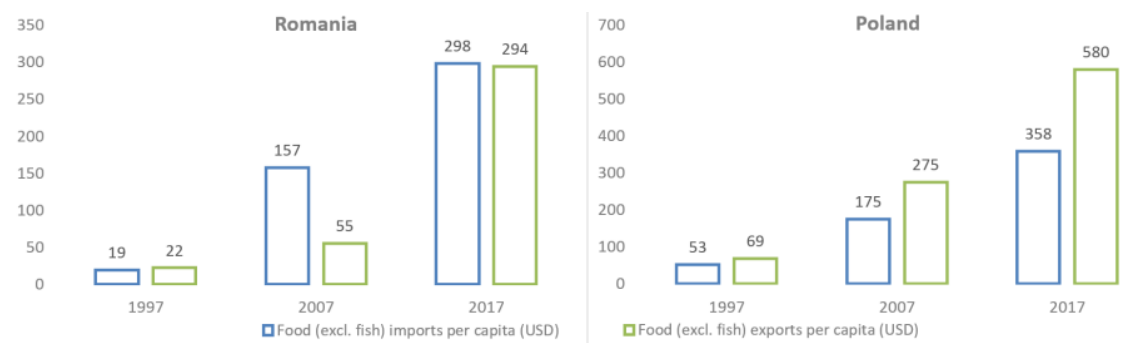

Figure 4. Food imports and exports per capita in Romania and Poland Source: Own representation based on FAO data (2019b)

It seem that high-income countries manage to transfer agricultural and water resources from low-in-come countries and in this way to displace the environmental costs of food production through trade, footprint emissions being assigned to exporting countries and not to those that consume the commodities (Holzeis et al., 2019). Beside fish, Poland succeeded to produce higher quantities for all categories of food: cereals, fruits and vegetables, meat and also dairy products and thus recorded in the last years higher values for their exports. Meat and pork especially from the history of Polish people was the most tastiest and valuable food, symbol of prosperity (Mroczkowska, 2019) which became one of the most valuable food categories produced and exported nowadays by Poland. After the entrance of multinational companies on the market of pork, as US Smithfield Foods did by processing more than 7 mill. pigs in 15 countries and a sales volume of 12 billion dollars each year they managed to control the entire European market imposing a small price for this category of goods, placing a huge pressure on small producers (Mroczkowska, 2019). Based on gross per capita production value Romania is ranked the $15^{\text {th }}$ country (2017) worldwide in producing crop and the $4^{\text {th }}$ in producing maize (FAO, 2019b). For this reaseon Romania also managed to export more than imports only cereals from all the food categories, with an important increase in the last years. 


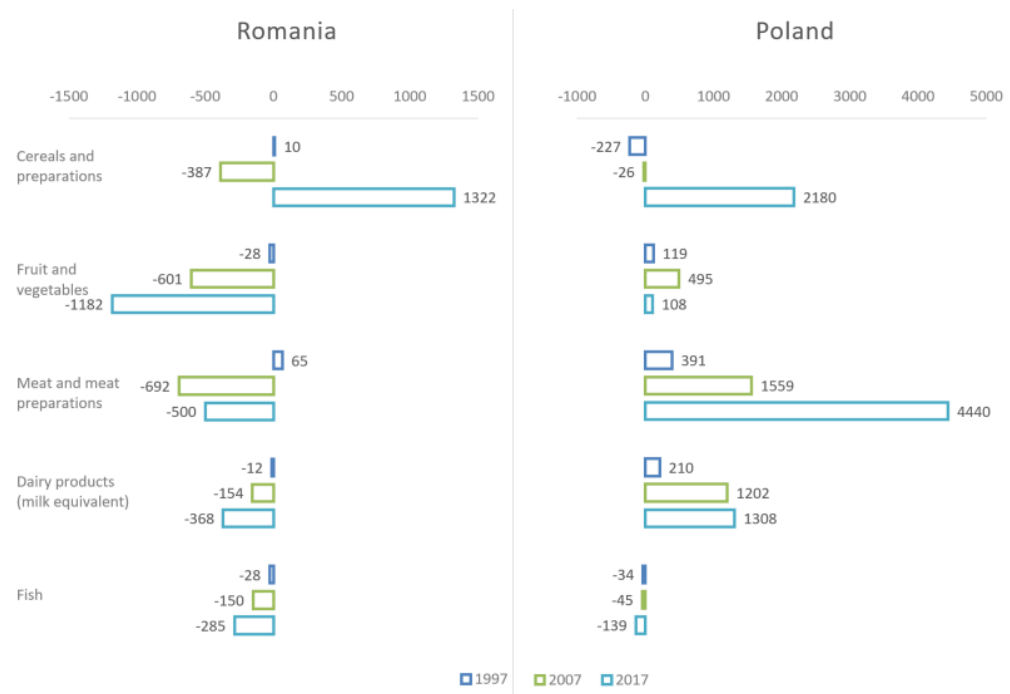

Figure 5. Net trade in Romania and Poland (mIn USD)

Source: Own representation based on FAO data (2019b)

Changes in eating habits can explain also net trade fluctuation in the last years being recorded a convergence of diets in increasing the consumption of meat (mainly chicken) and dairy products. Even if replacing animal based foods nutrients is a real challenge increasing vegetarian diets adopters could represent a sustainable way of development because of the reduced negative impact this category has on the environment in terms of carbon footprint compared to animal production (Notarnicola et al., 2017). Higher consumer expectations are observed, consumers are more eager to receive information on the production conditions, on the ingredients and other qualitative aspects of food, which is an arising trend in emerging countries. These influence the entire FSM - both processing industry and distribution need to be appropriate documented on all the relevant information and customer requirements (Fresco, 2009; Bene et al., 2019). Unfortunately there are an increasing number of obesity problems even among persons with low incomes and an increasing food waste in emerging countries. Poor nutrition lead to higher cost with the health system, an improvement and support for healthy diets are needed for the FSM by encouraging the production of health and nutrient rich foods like fruit and vegetables and important investments in food supply chain to reduce food loss.

\section{Conclusions}

The food system management plays a fundamental role in maintaining and improving food security and safety through innovation and productivity increase in a sustainable manner. Even if emerging countries don't place as much importance as they should on sustainable development and helping the local economy and small entrepreneurs, they are focusing more on supporting lacking capacities and food crises through policies and funds to deal with the unpredicted changes. 
Among the most important challenges identified in the food industry were: (1) income growth; (2) food poverty and obesity problems; (3) demographic changes; (4) the use of agricultural land; (5) increase in food production; (6) lack of specialized education; (7) intensification of imports and exports; (8) changes in eating habits; (9) higher consumer expectations. Particularly emerging economies as Romania and Poland have an unusual high average of energy supply, recording an increase of $7 \%$ in adult obesity in the last 20 years. Food poverty and the increased preference for processed food were the main factors that generated this situation. In terms of natural resources both Romania and Poland have important agricultural land areas, double than the world average, but with fewer workers in agriculture, representing half of the total number that worked in agriculture 20 years ago. There is an accentuated migration phenomenon especially in Romania which lead to a depopulation of both rural and urban areas, and different from other developed countries the percentage between rural and urban areas remained the same in the last 20 years both in Romania and Poland. The accession to European Union helped both countries to increase their production capacities through funds, better innovation and know-how transfer but at the same time this increased the competition and imports on the local market as it was the case of Romania, or contributed to a massive increase in exports for Poland. In terms of consumption habits there was recorded a growth of meat (chicken) and dairy products and at the same time consumer expectation are higher being egger to receive more information for the products they eat.

\section{Acknowledgement}

This work was cofinanced from the European Social Fund through Operational Programme Human Capital 2014-2020, project number POCU/380/6/13/125015 "Development of entrepreneurial skills for doctoral students and postdoctoral researchers in the field of economic sciences"

\section{References}

1. Bene, C., Prager, S.D., Achicanoy, H.A.E., Toro, P.A., Lamotte, L., Bonilla, C. and Mapes, B.R., 2019. Understanding food systems drivers: A critical review of the literature. Global Food Security, 23, pp. 149-159.

2. Bers, C. Van, Delaney, A., Eakin, H., Cramer, L., Purdon, M., Oberlack, C., Evans, T., Pahl-Wostl, C., Eriksen, S., Jones, L., Korhonen-Kurki, K. and Vasileiou, I., 2019. Advancing the research agenda on food systems governance and transformation. Current Opinion in Environmental Sustainability, 39, pp. 94-102.

3. Borawski, P., Be, A., Jozef, K. and Dunn, J.W., 2019. Land Use Policy Price volatility of agricultural land in Poland in the context of the European Union. Land Use Policy, 82, pp. 486-496.

4. Chaoniruthisai, P., Punnakitikashem, P. and Rajchamaha, K., 2018. Challenges and difficulties in the implementation of a food safety management system in Thailand: A survey of BRC certified food productions. Food Control, 93, pp. 274-282. 
5. European Commission (EC). 2018. Assessment of Research and Innovation on Food Systems by European Member States. [Online] Available at: https://scar-europe.org/images/FOOD/Deliverables/Assessment_Research_ Innova tion.pdf. [Accessed 20 August 2019].

6. Food and Agriculture Organization of the United Nations (FAO). 2018. Sustainable food systems - Concept and framework. [Online] Available at: http://www.fao.org/3/ca2079en/CA2079EN.pdf. [Accessed 2 September 2019].

7. Food and Agriculture Organization of the United Nations (FAO). 2019a. FAO framework for the Urban Food Agenda. [Online] Available at: http://www.fao.org/3/ca3151en/CA3151EN.pdf. [Accessed 2 September 2019].

8. Food and Agriculture Organization of the United Nations (FAO). 2019b. World Food and Agriculture Statistical Pocketbook. [Online] Available at: http://www.fao.org/3/ca6463en/ca6463en.pdf. [Accessed 3 September 2019].

9. Fresco, L.O., 2009. Challenges for food system adaptation today and tomorrow. Environmental Science \& Policy, 12, pp. 378-385.

10. Himanen, S.J., Rikkonen, P. and Kahiluoto, H., 2016. Codesigning a resilient food system. Ecology and Society, 21(4), pp. 41-56.

11. Holzeis, C.C., Fears, R., Moughan, P.J., Benton, T.G., Hendriks, S.L., Clegg, M., Meulen, V. ter and Braun, J. Von, 2019. Food systems for delivering nutritious and sustainable diets: Perspectives from the global network of science academies. Global Food Security, 21, pp. 72-76.

12. Mroczkowska, J., 2019. Pork politics: The scales of home-made food in Eastern Poland. Appetite, 140, pp. 223-230.

13. Notarnicola, B., Sala, S., Anton, A., Mclaren, S.J., Saouter, E. and Sonesson, U., 2017. The role of life cycle assessment in supporting sustainable agri-food systems: A review of the challenges. Journal of Cleaner Production, 140, pp. 399-409.

14. Reardon, T., Echeverria, R., Berdegué, J., Minten, B., Liverpool-tasie, S., Tschirley, D. and Zilberman, D., 2019. Rapid transformation of food systems in developing regions: Highlighting the role of agricultural research \& innovations. Agricultural Systems, 172, pp. 47-59.

15. Rey, R., 2015. New Challenges and Opportunities for Mountain Agri-Food Economy in South Eastern Europe. A Scenario for Efficient And Sustainable Use Of Mountain Product, Based On The Family Farm, In An Innovative, Adapted Cooperative Associative System - Horizon 2040. Procedia Economics and Finance, 22, pp. 723-732.

16. Thompson, C., Smith, D. and Cummins, S., 2018. Social Science \& Medicine Understanding the health and wellbeing challenges of the food banking system: A qualitative study of food bank users, providers and referrers in London. Social Science \& Medicine, 211, pp. 95-101. 